\title{
EXPERIENCE OF USING THE "ANTI-PLAGIARISM. HIGHER SCHOOL INSTITUTION" SYSTEM IN THE COURSE OF CHEMISTRY FOR STUDENTS OF ENGINEERING ACADEMY RUDN
}

\author{
E.Yu. Nevskaya, O.A. Yegorova, Yu.V. Kozhukhova \\ Peoples' Friendship University of Russia \\ Miklukho-Maklaya str., 6, Moscow, Russia, 117198
}

\begin{abstract}
When checking the written work of students each teacher faced with the problem of determining the originality of the work. At the department of General Chemistry RUDN University the system "Anti-plagiarism. Higher School Institution" is used for this purpose. Using this system when checking the work for borrowings from online sources, saves the teacher the routine of searching for matching blocks. In addition, the using of this system is aimed at improving the implementation of a culture of scientific citation, without which no research project in chemistry can be done, is aimed at increasing the level of scientific educational process of the students.
\end{abstract}

Key words: student plagiarism, online borrowing, system "Antiplagiat. Higher School Institution" quality control of students' written works

Peoples' Friendship University Academy of Engineering, with its rich set of various specializations is recruiting students to all forms of education. Teaching Chemistry is carried out both at the Full-time, Correspondence and Evening/Part-time Departments. The academic discipline "Chemistry" forms and organizes the scientific outlook, necessary for the Engineering Academy students. Unfortunately, the image and prestige of Chemistry as an academic discipline, is not high enough. This is due both to the low level of knowledge in Chemistry, and general knowledge. In addition, many students feel that learning chemistry is not necessary. Another specific problem faced by the teachers of the Peoples' Friendship University of Russia, is a large number of international students with different levels of knowledge of the Russian language.

The level and nature of teaching Chemistry is what students see in the first place. Therefore, the main objective of teaching the discipline "Chemistry" is not only providing the high-quality presentation of the material, but also increasing the reputation of chemistry as an academic discipline. The need to form the ability to formulate their own thoughts and the ability to express them intelligently and logically both orally and in writing is also important. Therefore, some courses and specializations in the Academy of Engineering envisage such forms of assessment, as an essay or a term paper in the kinds of academic activity. The information-packed space often makes the students use not only their own logical reasoning, but also a variety of the available sources of information, often not caring about the originality and uniqueness of their work. The percentage of students turning to online resources and submitting openly borrowed content for checking 
as their work, not caring for the originality of the stated material and grammatically correct text is high enough.

In evaluating different types of term papers and essays, in which there is a high percentage of plagiarism, there is no purpose to prove that the information was borrowed for the extraction of income or that it caused major material damage, the consequences of which are the various types of liability, including criminal [1-3]. The purpose of the detection of the borrowed content is to determine the level of inconsistency and lack of independence of the student and it is aimed at improving the quality of the teachers' work; and the implementation of a culture of scientific citation, without which no research project in chemistry can be done, is aimed at increasing the level of scientific educational process of the students.

It must also be taken into consideration that only a few students were taught how to write an essay in the secondary school, but most of them have no idea how to do it. There are some obvious, but obligatory rules they have to be reminded to observe. For example, it should be explained to the students that verbatim copying from textbooks or somebody else's articles is forbidden, but quotations can be used. "Any quotation, however small, must be placed in quotation marks or clearly indented beyond the regular margin" [6. P. 42]. It is also necessary to remind the students that all of the essay cannot consist only of quotations even from different sources. However, it must be underlined that mathematical equations or chemical formulae can be used as they are considered to be general knowledge. "Some ideas, facts, formulae and other kinds of information which are widely known and considered to be in the 'public domain' of common knowledge do not always require citation" [6. P. 43].

The third rule is about footnotes and bibliography. All the sources should be listed in the bibliography or references at the end of the article. According to Robert Harris, a specialist in anti-plagiarism strategies [5], conveying this information to the students in time will help the teacher to encourage students to do their own work and in this way to enrich their own education. Plagiarism is not a purely Russian problem. In his article "On detection of borrowing for the examination of scientific articles", head of the project "Anti-plagiarism" Yu.V. Chekhovich notes that the tendency to use someone else's intellectual work was revealed in the middle of the nineties of the 20th century "in parallel with the development of information technology and Internet resources" [4].

To find the source of borrowing from the Internet and compare it with the internal databases since 1997, abroad they use "Turnitin", a system developed by the American company iParadigms. Of a sufficiently large number of alternative services, allowing teachers to detect student plagiarism in academic and research work, since 2012 the Peoples' Friendship University of Russia (PFUR) has been using the system "Antiplagiarism. Higher School Institution", designed in 2005 by the company Forecsys. The Peoples' Friendship University of Russia was one of the first universities, which began to apply a mandatory test to essays, term and degree papers of students on plagiarism. The basic principle of this system is the comparison of the text works of students, in order to find in them completely identical or partially overlapping fragments that require a confirmation of their unique character in comparison with the collections of abstracts, written tests and textbooks that are stored in the database of the system. 
For example, students-geologists of speciality 130101 "Applied Geology" with specializations: "Geological survey, prospecting and exploration of solid minerals" and "Oil and Gas Geology" must complete a research paper: "Qualitative analysis of mineral..." as a productive essay in the second semester of their first year. Geologists and mineralogists often resort to the help of qualitative analysis and use its results in their practical work. The purpose of writing an abstractive-analytical work is to develop the ability to analyze a complex natural system - mineral, forecast the conditions for each specific reaction of ions detection and indicate their analytical effects, prove the consistency of the selected method of research, summarize the results and draw conclusions. Before doing the work the students get acquainted with the materials and recommendations on preparing the essay. They inform the teacher about their choice of the name of the mineral from the list, the qualitative analysis of which they will perform in theory. By the appointed time the completed essay is sent to the teacher's e-mail address and checked for originality. The teacher's e-mail address is given to the students directly before the time they have to submit their essays. The format of e-mail is quite convenient, since by default all messages are automatically saved, therefore you can always check the time of sending and the time of receipt of the desired letter.

Using the system "Anti-plagiarism. Higher School Institution" when checking the work for borrowings from online sources, saves the teacher the routine of searching for matching blocks. When working with the system via the website, the teachers themselves load the works received from the students in electronic form in one of the supported formats into their personal account to check. Later after the download, the teacher receives a generated report on the check of the document (the student's essay). The report identifies those pieces of verifiable documents that were found in the sources collection of the system "Anti-plagiarism. Higher School Institution" and also indicates the ratio of borrowed and original text in it.

Below there is an example of the received report on the check-up of an essay by a student-geologist with the record book number 1032130651.

Document Information:

The name of the source file: "Qualitative analysis of mineral: Wolframite manganous (Fe,Mn)WO4".docx

\begin{tabular}{|c|c|l|c|c|c|}
\hline$\square$ & Cached copy & \multicolumn{1}{|c|}{ Source reference } & $\begin{array}{c}\text { Search collection/ } \\
\text { module }\end{array}$ & $\begin{array}{c}\text { Percentage } \\
\text { in the report }\end{array}$ & $\begin{array}{c}\text { Percentage } \\
\text { in the text }\end{array}$ \\
\hline$\square$ & [1] Wolframite & $\begin{array}{l}\text { http://ru.wikipedia.org/wiki/ } \\
\text { Вольфрамит }\end{array}$ & Internet (Antiplagiarism) & $31,44 \%$ & $31,44 \%$ \\
\hline$\square$ & [2] Wolframite & $\begin{array}{l}\text { http://dic.academic.ru/dic.nsf/ } \\
\text { ruwiki/1290234 }\end{array}$ & Internet (Antiplagiarism) & $0 \%$ & $30,23 \%$ \\
\hline
\end{tabular}

Partially original blocks: $0 \%$

Original blocks: $68,56 \%$

Citations from the «white» sources: $0 \%$

Final assessment of originality: $68,56 \%$

The report analysis showed the percentage of originality $68.56 \%$, which according to the order of the Rector of the University "On improving the efficiency of work with the system "Anti-plagiarism. RUDN" meets the requirements of the degree of originality of the text. For the students of the Engineering Faculty the degree of originality, under which the test result of the works in natural sciences is interpreted as positive, should not be less 
than $50 \%$. Consequently, the work submitted with the percentage of the originality above the positive minimum is allowed for oral defense of the essay.

Further we present another report on the verification of the essay of the studentgeologist, record book number 1032130393.

Document Information:

The name of the source file: "Qualitative analysis of mineral: Linarite $(\mathrm{Pb}, \mathrm{Cu}) \mathrm{SO}_{4}(\mathrm{~Pb}, \mathrm{Cu})[\mathrm{OH}]_{2}$ ".docx

\begin{tabular}{|c|l|l|c|c|c|}
\hline$\square$ & Cached copy & \multicolumn{1}{|c|}{ Source reference } & $\begin{array}{c}\text { Search collection / } \\
\text { module }\end{array}$ & $\begin{array}{c}\text { Percentage } \\
\text { in the report }\end{array}$ & $\begin{array}{c}\text { Percentage } \\
\text { in the text }\end{array}$ \\
\hline$\square$ & [1] Source 1 & $\begin{array}{l}\text { http://knowledge.allbest.ru/che } \\
\text { mistry/3c0a65635a3ad78b4d4 } \\
\text { 3a8... }\end{array}$ & Internet (Antiplagiarism) & $85,29 \%$ & $85,29 \%$ \\
\hline$\square$ & [2] Source 2 & $\begin{array}{l}\text { http://revolution.allbest.ru/ } \\
\text { chemistry/00327486_0.html }\end{array}$ & Internet (Antiplagiarism) & $0 \%$ & $85,29 \%$ \\
\hline
\end{tabular}

Partially original blocks: $\mathbf{0 \%}$

Original blocks: 14,5\%

Citations from the «white» sources: $0 \%$

Final assessment of originality: $\mathbf{1 4 , 5 \%}$

The submitted work has not passed the test for plagiarism. To his/her e-mail address the student is sent a notification of the low quality of the submitted essay, which casts doubt on the author's knowledge and skills, so it is proposed that he/she should rewrite the work.

The general percentage of the originality of the works in group EGC-101 according to the results of the checks for plagiarism is shown in Fig. 1:

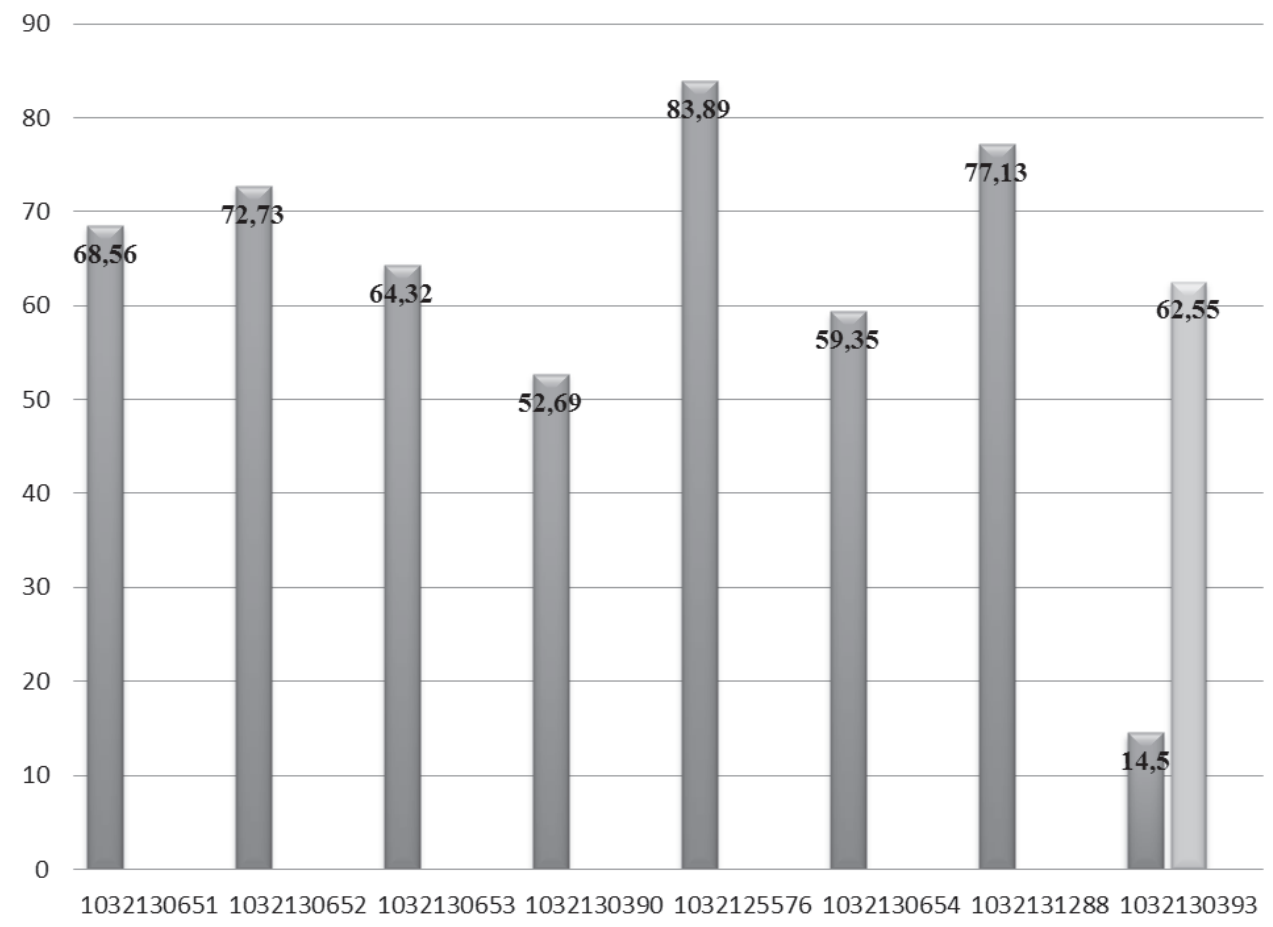

Fig. 1. Percentage of originality according to the result of checking student works for plagiarism in Group EGC-101 
It is believed that the system "Anti-plagiarism. RUDN" is protected from the substitution and transposition of symbols, words or letters, substituting with similar terms and cannot be bypassed by an automatic originality increase program "Antiplagiarism Killer". Since every system is flawed, unconscientious students enhance the uniqueness of their works in various ways, avoiding "Antiplagiarism. RUDN". Therefore, to give the objective points for an essay, an oral defense of the essay is provided.

It is unacceptable to use only the results of checks for incorrect borrowing as the sole and decisive criteria while setting the final score of the student's work. Total points for the work are summarized based on the percentage of originality according to the results of the checks for plagiarism, absolute command of the subject, the ability to present the results of the research paper convincingly.

\section{LITERATURE}

[1] The Civil Code of the Russian Federation, p. 4, Articles 1253, 1301, 1311, 1472, 1515, 1537.

[2] Code of the Russian Federation on Administrative Violations, Article 7.12 «Violation of copyright and related rights and patent rights».

[3] The Criminal Code (Criminal Code of RF), Article 146 "Violation of copyright and related rights".

[4] Chekhovich Yu.V. On detection of borrowings during the examination of scientific articles // Journal of Scientific Periodicals: Problems and Solutions. No. 4 (16), July-August 2013. Pp. 22-25.

[5] Harris R. (2015, May 18). Anti-Plagiarism Strategies for Research Papers. Retrieved July 25, 2016. URL: http://www.virtualsalt.com/evalu8it.htm

[6] Standler R.B. (2000, 2012, April 16). Plagiarism in colleges in USA. Legal aspects of plagiarism, academic policy. Retrieved July 20, 2016. URL: http://www.rbs2.com/plag.htm

(C) Nevskaya E.Yu., Yegorova O.A., Kozhukhova Yu.V., 2017

\section{Article history:}

Received: 19 January, 2017

Accepted: 28 February, 2017

\section{For citation:}

Nevskaya E.Yu., Yegorova O.A., Kozhukhova Yu.V. (2017) Experience of using the "Anti-plagiarism. Higher school institution" system in the course of chemistry for students of engineering academy RUDN. RUDN Journal of Informatization Education, 14 (2), 213-219.

\section{Bio Note:}

Nevskaya Elena Yurevna, Candidate of Chemistry, associate professor, associate professor of the general chemistry of faculty of physical and mathematical and natural sciences of the Russian Peoples' Friendship University.

Contact information: e-mail: sci@rudn.university

Egorova Olga Anatolyevna, Candidate of Chemistry, associate professor, associate professor of the general chemistry of faculty of physical and mathematical and natural sciences of the Russian Peoples' Friendship University.

Contact information: e-mail: sci@rudn.university

Kozhukhova Yulia Vladimirovna, senior teacher of department of foreign languages of faculty of physical and mathematical and natural sciences of the Russian Peoples' Friendship University. Contact information: e-mail: sci@rudn.university 


\title{
ОПЫТ ИСПОЛЬЗОВАНИЯ СИСТЕМЫ «АНТИПЛАГИАТ. ВУЗ» В КУРСЕ ХИМИИ ДЛЯ СТУДЕНТОВ ИНЖЕНЕРНОЙ АКАДЕМИИ РУДН
}

\author{
Е.Ю. Невская, О.А. Егорова, Ю.В. Кожухова \\ Российский университет дружбы народов \\ ул. Миклухо-Маклая, 5, Москва, Россия, 117198
}

При проверке письменных работ, учащихся каждый преподаватель сталкивался с проблемой определения оригинальности работы. На кафедре общей химии для этих целей используется система «Антиплагиат. ВУЗ». Использование «Антиплагиат. ВУЗ» при проверке работы на заимствования из сетевых источников избавляет преподавателя от рутинного поиска совпадений. Также использование этой системы способствует внедрению культуры научного цитирования, без которого не обходится ни одна научно-исследовательская работа по химии и на повышение уровня научно-образовательного процесса у студентов.

Ключевые слова: студенческий плагиат, интернет заимствования, система «Антиплагиат. ВУЗ», контроль качества письменных работ учащихся

\section{REFERENCES}

[1] The Civil Code of the Russian Federation, p. 4, Articles 1253, 1301, 1311, 1472, 1515, 1537.

[2] Code of the Russian Federation on Administrative Violations, Article 7.12 "Violation of copyright and related rights and patent rights".

[3] The Criminal Code (Criminal Code of RF), Article 146 "Violation of copyright and related rights".

[4] Chekhovich Yu.V. On detection of borrowings during the examination of scientific articles // Journal of Scientific Periodicals: Problems and Solutions. No. 4 (16), July-August 2013. Pp. 22-25.

[5] Harris R. (2015, May 18). Anti-Plagiarism Strategies for Research Papers. Retrieved July 25, 2016. URL: http://www.virtualsalt.com/evalu8it.htm

[6] Standler R.B. (2000, 2012, April 16). Plagiarism in colleges in USA. Legal aspects of plagiarism, academic policy. Retrieved July 20, 2016. URL: http://www.rbs2.com/plag.htm

\section{История статьи:}

Дата поступления в редакцию: 19 января 2017

Дата принятия к печати: 28 февраля 2017

\section{Для цитирования:}

Невская Е.Ю., Егорова О.А., Кожухова Ю.В. Опыт использования системы «Антиплагиат. Вуз» в курсе химии для студентов инженерной академии РУДН // Вестник Российского университета дружбы народов. Серия «Информатизация образования». 2017. Т. 14. № 2. С. 213219.

Сведения об авторах:

Невская Елена Юрьевна, кандидат химических наук, доцент, доцент кафедры общей химии факультета физико-математических и естественных наук Российского университета дружбы народов.

Контактная информация: e-mail: sci@rudn.university 
Nevskaya E.Yu., Yegorova O.A., Kozhukhova Yu.V. RUDN Journal of Informatization in Education, 2017, 14 (2), 213-219

Егорова Ольга Анатольевна, кандидат химических наук, доцент, доцент кафедры общей химии факультета физико-математических и естественных наук Российского университета дружбы народов.

Контактная информация: e-mail: sci@rudn.university

Кожухова Юлия Владимировна, старший преподаватель кафедры иностранных языков факультета физико-математических и естественных наук Российского университета дружбы народов.

Контактная информация: e-mail: sci@rudn.university 